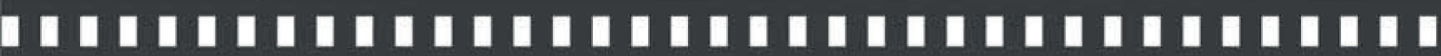

\author{
0 ícone da derrota: a construção \\ do $7 \times 1$ pela plasticidade visual
}

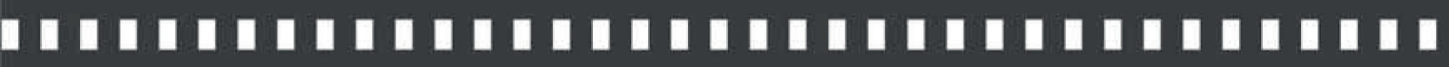

Magnos Cassiano Casagrande

Fabiano Maggioni

Artigo recebido em: 03/06/2016

Artigo aprovado em: 02/12/2016 


\title{
0 ícone da derrota: a construção do 7x1 pela plasticidade visual ${ }^{1}$
}

\author{
The icon of defeat: the 7x1 construction by visual plasticity \\ Magnos Cassiano Casagrande* e Fabiano Maggion;**
}

\begin{abstract}
Resumo: Oestudo investiga a derrota de $7 x 1$ da seleção brasileira na Copa do Mundo de Futebol de 2014 pela plasticidade da imagem. O fato foi reconstruído pelas forças plásticas que atuam na imagem, analisadas através de Villafañe (2000), Arnheim (1988) e Kandinsky (1997). As análises tornam mais evidentes as colaborações estratégicas das imagens usadas em capas de jornal na formação dos sentidos gerais que o texto pretende e mostram a flexibilidade do icônico para representar o real, através de elementos como a cor, o ponto, a textura e a dimensão.
\end{abstract}

Palavras-chave: Imagem. Sentidos. Plasticidade. Copa do Mundo de Futebol.

\begin{abstract}
The study investigates the 7x1 defeat of the Brazilian team in the football World Cup 2014 by the plasticity of the image. Plastic forces acting on the image analyzed by Villafañe (2000), Arnheim (1988) and Kandinsky (1997) reconstructed the fact itself. The analysis becomes more evident the strategic collaboration of the images used in newspaper front pages, in the formation of the general directions that newspaper text intends and shows the flexibility of the iconic to represent the real through visual elements such as color, point, textures and dimension.
\end{abstract}

Keywords: Image. Senses. Plasticity. Football World Cup.

1 Texto produzido com apoio da Coordenação de Aperfeiçoamento de Pessoal de Nível Superior (CAPES).

* Doutorando do Programa de Pós-Graduação em Comunicação da Universidade Federal de Santa Maria (POSCOM-UFSM). Mestre em Comunicação pela Universidade Federal de Santa Maria. Desenvolve pesquisas na área de Comunicação e Esporte, Análise do Discurso e Narrativas Midiáticas. Membro da equipe editorial da Revista Interamericana de Comunicação Midiática Animus. 


\section{Introdução}

O acontecimento gera imagens - ou possibilita a geração de imagens a partir dele -, que podem ser tomadas ou capturadas pelas lentes fotográficas, mesmo que apenas em fragmentos, serem utilizadas em montagens ou servirem de base - considerando-as como algo que fica registrado na mente dos sujeitos - para a produção de outras materialidades como desenhos, charges, ilustrações etc. Os grandes jogos de uma Copa do Mundo de Futebol, como a derrota da seleção brasileira pelo placar de sete (7) gols a um (1) para a seleção alemã na semifinal da edição de 2014, produzem imagens que carregam uma valoração e uma significação capazes de versarem e serem utilizadas para representarem um acontecimento.

Parte-se do princípio de que a imagem tem o potencial de atuar entre o imaginário dos sujeitos e suas intencionalidades, no caso, sujeitos enunciadores de instâncias midiáticas que manifestam-se através da capa de um jornal impresso. Desse modo, a capa é utilizada para representar os sentidos da derrota e a imagem é considerada um de seus principais operadores. $\mathrm{O}$ artifício enunciativo aqui é a manchete principal da capa do jornal que, através da composição icônico-verbal, elabora um enunciado rico em vozes e contextos discursivos.

Assim, procura-se investigar que elementos visuais são utilizados nas capas de jornais impressos brasileiros para representar a derrota pelo placar de $7 \times 1$ da seleção masculina nacional para a seleção alemã na Copa do Mundo de Futebol de 2014 e como tais elementos visuais produzem sentidos acerca da derrota. Chamamos a importância para o elenco e a disposição dos elementos fundamentais da imagem e sua sintaxe, que na fotografia ** Professor Adjunto do Curso de Publicidade e Propaganda do Departamento de Ciências da Comunicação da Universidade Federal de Santa Maria UFSM. Doutor em Comunicação Midiática no POSCOM-UFSM. Mestre em Comunicação Midiática da UFSM. Desenvolve pesquisa nas áreas de estratégias de imagem, audiovisualidades, semiótica, charge e mercado. Editor-gerente da Revista Interamericana de Comunicação Midiática - Animus. 
e nas ilustrações configuram atmosferas de significado com força de síntese de fatos mais complexos. O mesmo também ocorre em enunciados como a charge jornalística.

Nas análises deste trabalho é possível encontrar um pensamento sobre os fatos dados pela notícia do jornal, através dos elementos visuais como a cor, da qual Kandinsky (1997) e Villafañe (2000) expõem suas capacidades sinestésicas. Tais elementos visuais denotam e potencializam as expressões e sentimentos das pessoas fotografadas, pelas posições do olhar, dadas pelo fotógrafo. Conceitos como o de peso visual também serão apontados nas análises para demonstrar as escolhas estratégicas da composição fotográfica na produção dos sentidos. Por seu turno, e como exemplo sucinto do que é tratado mais adiante, a relação interdiscursiva entre textos verbais e visuais acaba por explicitar o sarcasmo com que algumas imagens tratam o fato da goleada sofrida pelo Brasil.

Como consequência desse arranjo inicial de significados no texto icônico-verbal, brotarão sentidos da derrota manifestados através de imagens. Investiga-se como as imagens de capa, ou a própria capa quando tomada como uma imagem única, são capazes de representar a derrota e de abordar os gestos, as sensações e as reações. Parte-se do pressuposto que desenvolvem um sentido de raiva, de sarcasmo, de melancolia, de dramaticidade ou um espaço para exaltação da vergonha e do negativo. Tais sentidos ficam orbitando o fato da derrota e toda a comoção que esta gerou e que é demonstrado pela manchete principal das capas dos jornais.

O espaço que revela a superioridade de um frente a inferioridade do outro também é marcado pelo contexto dos números. Cabe adiantar que o fato em si da derrota é violentamente assinalado pelo placar, e este é dado na memória por números "7 $\mathrm{x}$ 1". A representação visual que cerca ou acompanha estes números, puxa para eles elementos de memória que ora os enfatizam, ora os substituem. 


\section{Considerações sobre a imagem}

As imagens são linguagem que suportam a carga idearia do humano, na relação que este mantém com a realidade. $\mathrm{O}$ homem as captura do ambiente natural, as reelabora em seu consciente e é capaz de produzi-las, em forma de discurso, para afirmar algo a alguém. Nesse instante faz uso dos elementos primários da linguagem visual para alcançar os objetivos de sua comunicação.

Como linguagem, as imagens cumprem papel importante nas relações de comunicação humana. Ao comunicar, o homem desenvolve o subjetivo, distanciando-se assim dos demais animais pela busca do aperfeiçoamento que faz da cadeia genética de sua espécie. Usar a linguagem visual para se comunicar constitui no homem a firmação de uma dimensão que o permitiu evoluir. Em sua descendência, o homem analisou e processou as informações que coletava do ambiente, e estas o permitiram se colocar em interação com os demais de sua espécie.

Como atribui Damásio (2011), essas ações fizeram surgir no homem a consciência, que o coloca como testemunha do mundo, além de organizar os padrões neurais de forma que ele consiga acessar o conhecimento. Por outras palavras, as imagens acumuladas na consciência fizeram o homem produzir sua cultura.

É na interação relacional entre os indivíduos da mesma espécie que se dão esses processos. Nela, o cérebro faz marcações simbólicas que permitem atribuir significado às coisas, aos eventos e ao outro. Na explicação de Meyer (2002, p. 78), os objetos são reconhecidos pelo cérebro na fase da percepção, em seguida são reconstruídos, devido à capacidade de análise, síntese e hierarquização desse órgão, pois “... não é o olho, mas sim o cérebro que vê".

Sendo assim, cada indivíduo constrói um mundo segundo suas percepções. As impressões deste mundo são capturadas, principalmente pelo campo sensorial da visão, ou ainda, nas palavras de Meyer (2002, p. 17), 
A aptidão do cérebro humano para categorizar sensações e para receber bilhões de estímulos caóticos, diferentes de pessoa para pessoa e muitas vezes não identificáveis, garante a criação de um mundo perceptual e semântico próprio de cada indivíduo, de onde emergem o pensamento e linguagem. Esse esquema é pouco discutido pelos cientistas.

Esta captura do real através de imagens oxigena a compreensão que o indivíduo faz do meio - mundo - onde vive. Acaba assim, por ordenar os acontecimentos da vida em uma teia organizada e diversa de sentidos que são expressos nas linguagens. Ao materializar as coisas que enxerga, vivencia ou faz, na forma de linguagem, o homem acaba imprimindo aos fatos que representa determinada condição de verdade. Ou lembrando as palavras de Deleuze (1974, p. 36), "precisamente porque tudo passa pela linguagem e se passa na linguagem".

Dentro deste contexto filosófico-biológico, acabamos por alargar a margem dispensada à imagem na composição de nossas representações. Tal fenômeno se dá pela produção frenética de imagens pelas tecnologias das novas mídias, que a usam como linguagem principal. A indagação criada no ramo dos estudos de imagemaindaé sobre como ela está se consolidando comolinguagem. Para nós, a cada análise de imagem surgem questionamentos acerca de como é a organização e a delimitação da gramática do icônico e como está cercado seu campo epistemológico?

Alguns dos autores usados neste trabalho ajudam a compor um pensamento sobre o assunto: caso de Justo Villafañe, pesquisador espanhol que normativamente classificou elementos visuais pela sua importância na formação da hierarquia visual. Como também de Rudolf Arnheim, que preferiu analisar as imagens já em seu processo de sintaxe, do obtido pela relação dos elementos principais atuantes na composição. Ou ainda do pintor Wassilly 
Kandinsky, que montou, segundo suas experiências artísticas e percepções de mundo, uma conceituação que pode servir de base para a elaboração de uma teoria da imagem.

\section{O 7x1 e a capa de jornal}

A representação do mundo é o propósito das imagens, pois atuam como "mediações entre o homem e o mundo" (FLUSSER, 2011, p. 23), colocando-se entre ambos. Para o autor, elas constituem uma encenação e são responsáveis pela construção de cenas. Como consequência, tem-se que através desse conjunto simbólico "o próprio mundo vai sendo vivenciado como um conjunto de cenas" (FLUSSER, 2011, p. 23). No campo dos esportes, especialmente em um megaevento como a Copa do Mundo de Futebol em que grande parte dos torcedores não possuem acesso presencial aos acontecimentos, o acesso a eles dá-se através de imagens - estáticas ou em movimento - vindas dos meios de comunicação.

Conforme Campos (2014, p.166), a interação entre torcedores e esporte dá-se "cada vez mais, com as imagens do esporte e não com o próprio esporte". Admite-se a ideia de que a imagem permite, independentemente de ser fotográfica ou não, pensar em uma interpretação mínima sobre um acontecimento. Nessa direção, pensa-se que a capa de jornal, ambiente sincrético que faz grande uso de imagens, pode ajudar-nos a pensar relações entre imagem e esporte.

Após um acontecimento como o resultado negativo de 7x1 da seleção brasileira frente a seleção alemã na semifinal da Copa do Mundo de Futebol de 2014, a preocupação das instâncias de enunciação jornalísticas recai menos sobre a escolha dos acontecimentos que estampariam a primeira página do jornal do que sobre o tratamento que será dado a um acontecimento específico. Destaca-se que em uma coleta inicial de capas para comporem o corpus da presente pesquisa, a derrota da seleção nacional ocupou 
grande parte ou todo o espaço da capa dos jornais encontrados ${ }^{2}$, algo que apenas grandes acontecimentos conseguem, o que demonstra o grande potencial do acontecimento em questão e a característica de variabilidade na composição e concepção da capa.

Em um acontecimento de grande magnitude para a cultura futebolística nacional não cabe apenas a produção de uma capa para diferenciar-se das publicações concorrentes mas, essencialmente, para funcionar como um agente de memória nos anos e em outras edições do evento que sucedem 2014. Em resumo, pode-se atribuir à capa de jornal uma função inicial de registro e outra de vestígio que faz lembrar os sentimentos do resultado de 7x1.

A capa é a primeira imagem do jornal, por isso, segundo Portari (2013), é a página da publicação que mais demanda cuidado na escolha de palavras, imagens e estrutura gráfica. Além disso, como detalha Verón (2004), a capa revela as primeiras proposições do enunciador ao destinatário na tentativa de estabelecimento de certo vínculo. Pode-se dizer que estão em jogo certos valores socioculturais que orientam a relação comunicacional entre os sujeitos. Desse modo, pensa-se que a capa é um objeto comunicacional, oriundo, mas não restrito, ao universo jornalístico.

Através da capa manifesta-se uma intencionalidade que, por vezes, é difícil de atingir, em virtude do alto grau de subjetivismo. É possível, no entanto, através das análises, ao menos apontar efeitos de sentido possíveis com a utilização de determinada imagem ou o que se deseja manifestar ou causar através de seu uso. Trata-se de um produto simbólico-cultural resultante do trabalho de um conjunto de enunciadores orientados por determinadas escolhas que, no entendimento de Brait (2012), conduzem a sentidos diferentes bem como revelam opiniões e o pensamento de tais sujeitos sobre um acontecimento.

Utilizando as palavras de Charaudeau (2006, p. 205), afirmase que o texto icônico-verbal no qual resulta a capa de jornal é "um

2 Coleta inicial propiciada pelo site B9, que disponibilizou 50 capas de jornais brasileiros sobre o placar de 7x1 (BRAINSTORM 9, 2014). 
texto portador de sentidos". Texto que explora, no acontecimento em questão, uma visada de captação do leitor, voltada para um fazer sentir que busca as emoções através da exploração de um resultado cercado, por exemplo, de drama, de vergonha e de melancolia.

Os sentidos de uma capa de jornal dependem, obviamente, não apenas do acontecimento, mas também dos elementos visuais utilizados e hierarquizados em sua construção. Portanto, o aspecto visual da capa é determinante no processo de compreensão e no acesso imaginário de um acontecimento. Através de Portari (2013), é possível dizer que a composição gráfica/visual auxilia no jogo de sentidos e nos tensionamentos presentes na primeira página. Apesar de ser composta por vários outros elementos ${ }^{3}$, a manchete e a imagem que a acompanha, geralmente, constituem a principal materialidade discursiva de uma capa de jornal.

\section{Os significados do visual}

As análises que seguem procuram evidenciar a importância dos elementos visuais básicos e suas sintaxes para a construção de um sentido maior, dado na narrativa icônica. Começa-se pela exposição do fato retratado pela capa do jornal e, em seguida, procura-se partir pela edificação plástica construída principalmente pela fotografia e alguns elementos gráficos postos sobre ela. Há que se considerar primeiramente que tais capas de jornais tentam explorar a criatividade da foto esportiva em meio a um esgotamento e exaustão de uso de ângulos, closes e motivos relativos ao futebol, nos noticiários esportivos cotidianos.

O histórico resultado de sete (7) gols para a seleção da Alemanha e um (1) gol para a seleção brasileira, na semifinal da Copa do Mundo de Futebol de 2014, possibilitou a transformação das capas dos jornais brasileiros em um espaço de compreensão e

3 Legendas, marca do jornal, anúncios publicitários, espaços em branco (PORTARI, 2013, p.58). 
de exposição de pensamentos e opiniões das instâncias midiáticas relacionados à derrota. Nota-se que temos, definitivamente, um acontecimento que é da ordem do descontínuo, como qualifica Quéré (2005). Apesar de descontínuo, nenhum acontecimento é impossível, destaca o autor. A partir dele volta-se para as "possibilidades, potencialidades e eventualidades" de sua existência, que é capaz de reconfigurar o mundo que a cerca, lançando novos olhares para acontecimentos passados e para aqueles que virão. Além disso, considera-se a inevitável influência sobre aqueles que sofreram ou foram afetados pelo acontecimento.

O fracasso de 2014 contrasta com uma trajetória composta mais por vitórias do que derrotas e não se compara aquelas ocorridas em outras em edições, à exceção do ocorrido em 1950, o popular Maracanaço, quando a seleção brasileira foi derrotada pela seleção uruguaia pelo placar de dois (2) gols a um (1) na final da competição. Os cinco títulos mundiais que sucederam 1950 configuram um ar de obrigatoriedade de vitória em toda competição que a seleção disputa. As derrotas passam a ser culpa praticamente exclusiva dos jogadores brasileiros e não da qualidade e efetividade do adversário (COSTA, 2008). O Maracanaço, portanto, transforma-se na referência mais próxima do acontecimento de 2014, fato que leva várias capas a qualificarem o 7x1 como Vergonhaço, Mineiraço e Salsichaço e utilizarem imagens para produzir tal significação.

As estratégias usadas evidenciam quebras no modo de enquadrar o fato esportivo e na brincadeira interdiscursiva com fatos que extrapolam as quatro linhas do campo, onde elementos gráficos ajudam bastante. 
Figura 1 - Capa do jornal Agora São Paulo

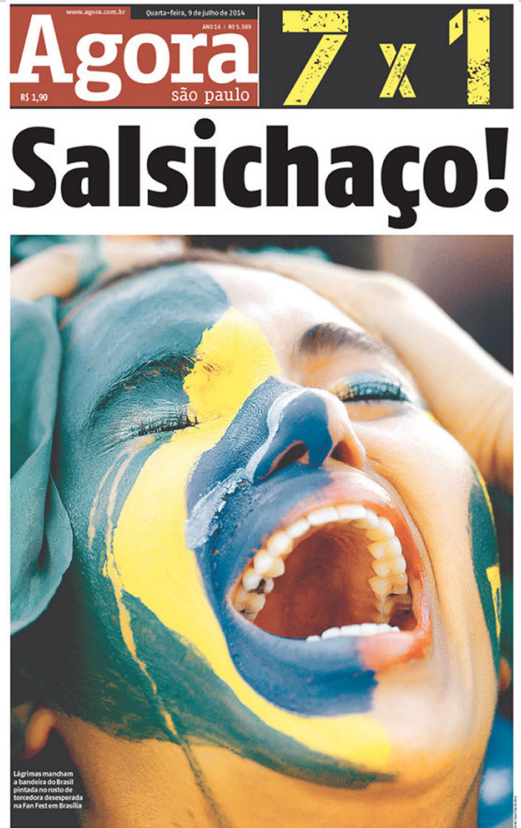

Seleção sofre a maior humilhação em 100 anos de história

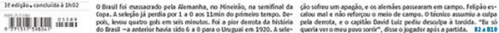

Fonte: Brainstorm 9 (2014).

A construção do fato trágico parte da capa, em relações interdiscursivas obtidas principalmente pelo recurso da imagem empregada. Neste caso, a derrota brasileira é representada com um plano em close no rosto da torcedora. A dor figurada aqui ganha destaque pelo enquadramento aproximado assumido na foto, pois nela, o drama é acentuado. Seu contra-plano, expressivo e de tom forte (POLVERINO, 2007) destaca a face e as expressões do sofrimento.

Faces fotografadas em posições oblíquas produzem o efeito de "escorzo" que segundo Villafañe (2000), ocorre quando a imagem não apresenta os aspectos de sua totalidade, sendo tomada por um de seus ângulos, mascarando assim sua forma habitual. Este 
efeito plástico, de caráter escalar, cria distorções e estranhamentos à imagem, acentuando aqui, o sofrimento humano. Tanto o close quanto o contra-plano tornam a foto da capa um enunciado extremamente expressivo e intenso.

A expressão e intensidade do sofrimento são potencializadas pela captura da torcedora com a boca aberta, provavelmente um grito pertencente a um choro, o qual faz desmanchar a pintura das cores da bandeira brasileira presente em sua face. Desmancha um dos símbolos do torcedor que se envolve inteiramente com uma partida de futebol, a pintura das cores de seu clube ou seleção na face. O close e o contra-plano revelam ainda a ação da torcedora de levar as mãos à cabeça, que acentua o sofrimento e demonstra a incredulidade no resultado.

O recurso gráfico que indica o placar do jogo " $7 \mathrm{x} 1$ " é posto em cor marrom claro manchado de pontos pretos. A plasticidade aqui desenha efeitos de sujidade e depreciação em letras demarcadas por linhas retas quebradas que, na visão de Kandinsky (1997), somam as forças plásticas fria e quente alternadas, que formam um ângulo de $45^{\circ}$ e sua exatidão normatiza a forma que desenha. Os efeitos produzidos levam-nos a pensar na pouca qualidade do futebol brasileiro apresentada na partida e ao longo da competição, algo referente a um futebol insuficiente, desiquilibrado, desorganizado, defasado e manchado pela organização que o comanda, a Confederação Brasileira de Futebol (CBF).

Nesta outra imagem, capa do jornal Correio pode-se perceber o mesmo efeito escalar de "escorzo" em duas fotografias. Primeira à esquerda, quando o contra-plano no rosto da mulher é delineado pela sua silhueta (posição oblíqua). 
Figura 2 - Capa do jornal Correio (Bahia)

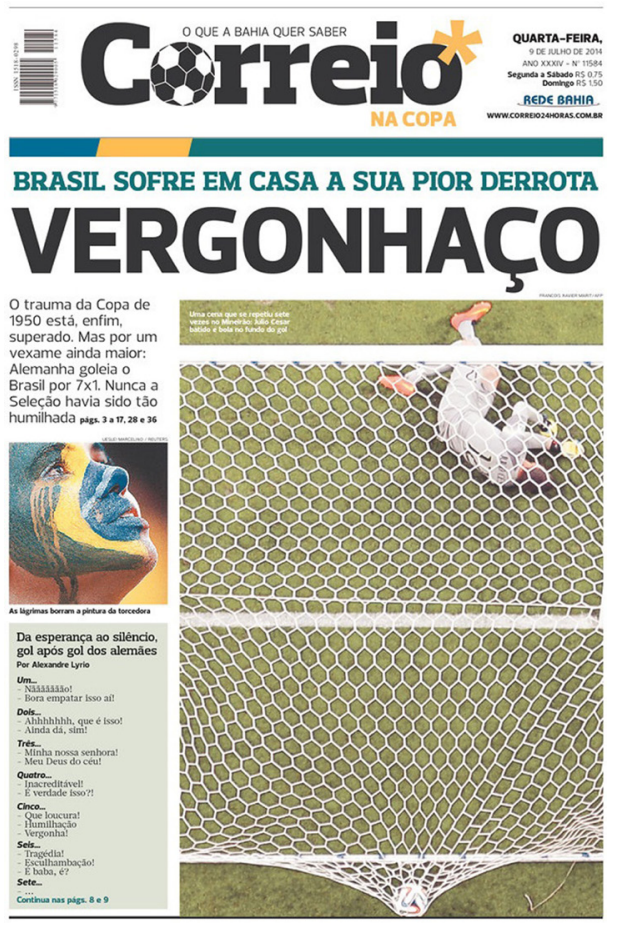

Fonte: Brainstorm 9 (2014).

Este conjunto de posições novamente acentua o sofrimento, ou a súplica aos céus, engendrado pelo enunciado fotográfico. Já à direita o efeito de "escorzo" ocorre num plano superior, apequenando o goleiro e subtraindo dele a maioria das formas. $\mathrm{O}$ formato "raso" criado pelo elemento visual escalar aqui, faz lembrar os movimentos das peças de um tabuleiro de xadrez, onde a peça "bola" ultrapassa a peça "goleiro", ganhando a partida.

$\mathrm{Na}$ sua composição hierárquica, esta imagem tem nítida influência da ação dos vetores plásticos. Tais vetores são, segundo Arnheim (1988), a representação plástica de situações físicas onde entende-se que os objetos de uma composição visual são um campo de energia. Quando este campo irradia energia pelo espaço plástico, 
criam-se vetores na iconicidade, que podem ser explícitos, uma linha reta, ou implícitos, como a direção de um olhar. Um destes vetores está implícito entre a bola e o goleiro, marcando a trajetória que ela fez até balançar a rede.

Sua desenvoltura no espaço plástico se destaca ainda mais por esticar a rede ao centro e a baixo, criando uma "seta" vetorial de velocidade. As três retas horizontais, marcadas pelas linhas das traves da goleira, equilibram o espaço, demarcam lugar de repouso, e isso é quebrado com a trajetória vetorial oblíqua da bola, que venceu o goleiro. Retas horizontais são equilibradas enquanto retas oblíquas são tensivas, pois congregam as forças quentes da verticalidade com as frias da horizontalidade (KANDINSKY 1997, p. 50).

A cena toda construída pela foto aqui, traça estratégias de sobrepor e dar ênfase à bola, chutada pelo adversário, que vetoriza o espaço plástico e que deixa uma vítima caída ao chão. O balançar da rede pela bola é o que conduz um ao êxtase e o outro à decepção. Junto com a vítima - o goleiro Júlio Cesar - cai a esperança do jogador selecionado, dos torcedores de vitória e da possibilidade de disputar uma nova final de Copa do Mundo no lendário estádio do Maracanã. Cai o sonho do hexacampeonato e a possibilidade de minimizar, ao menos simbolicamente, a derrota de 1950.

Em eventos que apresentam possibilidades de ângulos bastante explorados por fotógrafos, como é o caso de uma Copa do Mundo de Futebol, a foto criativa e inédita é muitas vezes obtida pelo estranhamento das posições de câmera e lentes usadas pelo fotógrafo. Os efeitos criados são os das distorções das formas, caso novamente do "escorzo". Vejamos nas imagens a seguir. 
Figura 3 - Capas dos jornais Diarinho (à esquerda) e Diário de Santa Maria (à direita)

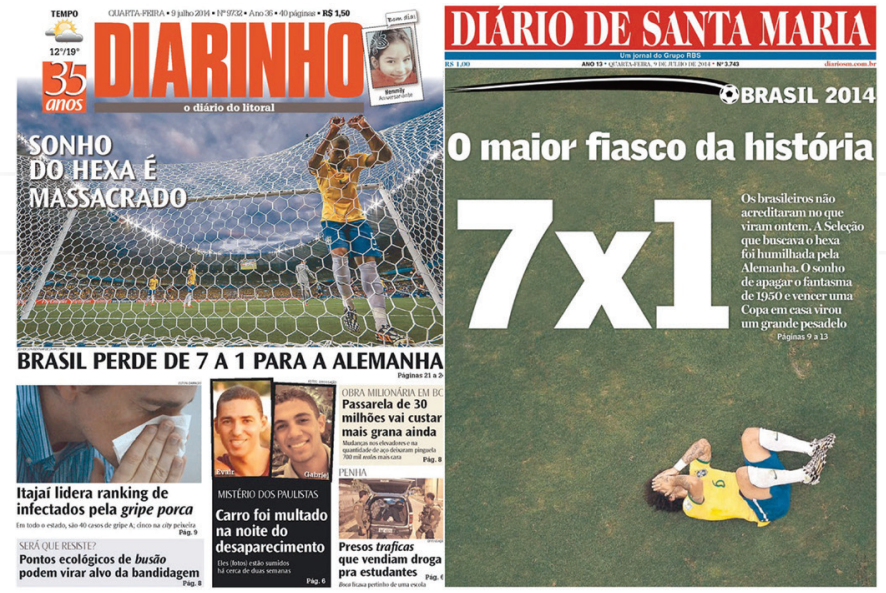

Fonte: Brainstorm 9 (2014).

Na capa do Diarinho, à esquerda na Figura 3, vemos um contra-plano feito por de trás das redes da goleira. Como já dito, são planos expressivos, engrandecem o objeto fotografado pois the dão amplitude de tamanho ao mesmo tempo que mudam sua forma. Possivelmente na referida foto foi usada uma lente grande angular que permite alargar o primeiro plano.

As distorções visuais agravam os sentidos da notícia em que a imagem faz parte, fogem do equilíbrio pretendido pela visualidade humana (ARNHEIM, 1988) e tensionam a interpretação do que é visto. Na figura é possível perceber as distorções no ângulo da trave da goleira, que parece "deitar-se", puxando a rede sobre o jogador e pronta para "encobrir" os demais. O corpo do jogador que se apoia na rede também está inclinado para a esquerda, na distorção promovida na foto. A cena em que a rede e o jogador Fernandinho - cabisbaixo encontram-se não revela outra situação senão a lástima. A rede que encobre Fernandinho funciona como um ponto de sustentação diante do massacre imposto pelo 
selecionado alemão que, como diz a manchete, coloca fim ao sonho do hexacampeonato. A rede transforma-se no ponto de encontro da derrota com seu derrotado.

Outro fator visual que se destaca na imagem é a construção do peso visual da mesma. Nota-se que há harmonia na distribuição dos elementos que compõem a imagem pela cena, o arco formado pelo contorno superior do estádio é equilibrado e forma um "V" que transpassa a imagem e parece apoiar-se nas estruturas verticais/ oblíquas da goleira. Esse "V" formado pelo arco desenha na foto um vetor harmonioso, espalhando energia pelo espaço plástico, imprimindo assim mais movimento à imagem (VILLAFAÑE, 2000, p. 147).

Por seu turno, a distorção promovida na foto, pelo ângulo de enunciação visual que o fotógrafo assumiu, faz engrandecer a horizontalidade do chão, o gramado. Desta grande linha horizontal partem os vetores visuais que delineiam o restante da imagem. Assim, o chão ganha peso visual e, ao mesmo tempo que normatiza a distribuição dos jogadores, arquibancada, arco e goleira, amortiza o olhar pela base que constrói para ele.

O peso visual construído aqui é tão forte que o chão - elemento horizontal - atrai o jogador apoiado na rede - elemento vertical -, pois como argumenta Arnheim (1988), as verticalidades estão mais explicitamente ligadas ao solo, diferente das horizontalidades que, quando deitadas no horizonte parecem mover-se paralelas a ele, sofrendo pouca atração.

Já na capa do Diário de Santa Maria (à direita), vê-se o jogador brasileiro jogado ao chão e acima dele, o coadjutante do fato reportado nas manchetes, o placar. Mais uma vez a posição assumida pela máquina fotográfica - aqui possivelmente sustentada por um dispositivo suspenso no campo - desfez a estrutura original das formas que estão ali representadas. Ou nas palavras de Villafañe (2000), sugere-se a totalidade da imagem apenas por uma parte.

No quadro hierárquico visual, ganha ênfase na capa o desequilíbrio proposital ocasionado pelo peso visual do jogador. Ele 
fica caído e isolado no canto direito inferior da imagem enquanto que, sobre ele, pesa o placar. Desenhado em severas e espessas linhas retas quebradas, que expressam a dureza das energias frias e quentes do ângulo de $45^{\circ}$, segundo Kandinsky (1997). Novamente o elemento plástico colabora sobremaneira para a formação do sentido do texto. Segundo Arnheim (1988), o peso visual é gerado também pela proximidade ou distanciamento do ponto de maior atração ou pela posição dos elementos na cena.

Neste caso reforçam o isolamento do jogador, sua posição em relação ao placar, sua relação de tamanho com ele e sua posição inferior, quando o placar, maior, tende a buscar o chão na analogia que este faz à lei da gravidade. Também porque há um vazio ao lado do jogador e ele "deseja" ser ocupado para que o espaço plástico volte a se equilibrar.

Outro efeito plástico bastante usado para composição das capas que ilustram a derrota na Copa do Mundo é a temporalidade. Característica das imagens fixas que se põem em sequência de tempo, ao longo da narrativa icônica criando significações. Como bem explica Villafañe (2000, p. 139),

Hay dos formas de temporalidad icónica que originan, como he apuntado, anteriormente, dos tipos de imágenes diferentes: las secuenciales y las aisladas. Las primeras, como su nombre indica, se basan en una estructura temporal de secuencia [...] el orden temporal de las imágenes aisladas está basado en la simultaneidade.

Esta simultaneidade é dada nas capas de jornais pela forma como abordam um assunto, de forma sequenciada e simultânea. Vejamos as figuras abaixo: 
Figura 4 - Capa do jornal A Gazeta

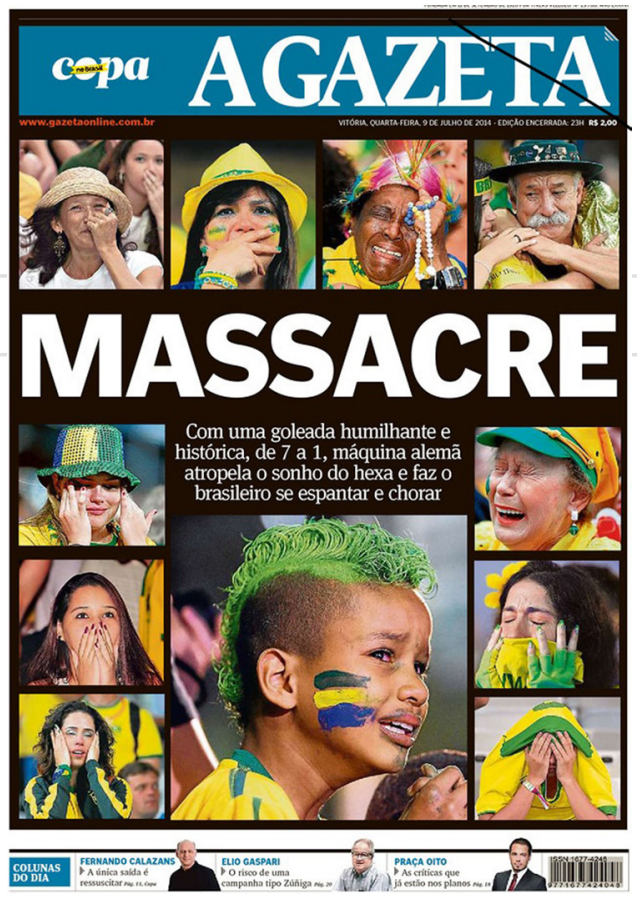

Fonte: Brainstorm 9 (2014).

A imagem monta um interdiscurso com o dito popular "A moldura dor, do quadro do sofrimento", onde retrata várias fotos de closes sofríveis em torno do fato. O que chama a atenção é a disposição sequenciada, como se a narrativa fosse posta em flashes estratégicos, na indução de um ritmo de leitura que reforçam sentidos em torno da derrota. Não há sequência cinética ali, porém a transitoriedade e o modo simultâneo como é dada a leitura das imagens, cada uma apresentando um tempo e um espaço definido, induzem ao efeito de movimento. Entre os quadros há elipses de uma narrativa visual desconjunturada porém, unida em torno do fato maior, perene e recordado na composição pela palavra "MASSACRE", que está sobreposta à sequência de quadros. 
Outro exemplo da temporalidade atuando em espaços distintos, mas criando nexos de continuidade é dado pela capa da Figura 5.

Figura 5 - Capa do jornal Diário de Pernambuco

\section{DIARIO PERNAMBUCO}

\section{Barbosa, descanse em paz}

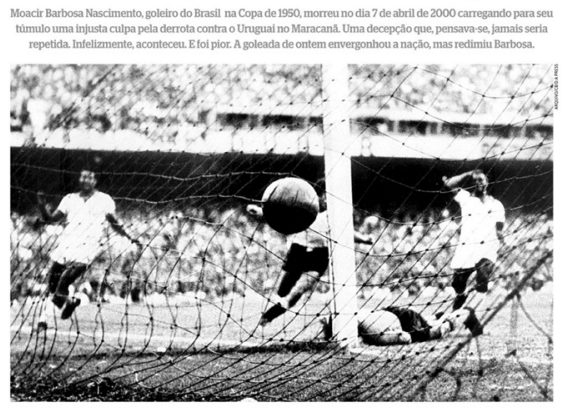

O PIOR DIA DO FUTEBOL BRASILEIRO

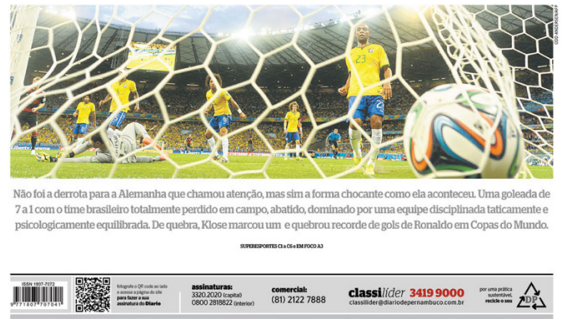

Fonte: Brainstorm 9 (2014).

As duas imagens da capa acima tem espaço e tempo definidos e fechados. Elas interpretam, expressam e recriam uma ação que foi desenvolvida em um espaço fechado. A natureza destas duas imagens corresponde ao que Villafañe (2000) chama de descritivas. Mas há um elemento mais nesta capa. As duas imagens com tempo e espaço distintos são postas juntas formando uma nova 
imagem, com dois tempos de leitura vertical. De certo modo, criase um efeito interdiscursivo onde um fato do passado - final da Copa do Mundo de 1950, em 16 de julho - encontra sentidos comuns a um fato contemporâneo, Copa do Mundo de 2014. Além disso, as imagens colaboram para uma releitura/refiguração do fato de 1950 pelo fato de 2014 .

Este efeito é comum em sequências de quadros das histórias em quadrinhos, onde o espaço dos quadros não é fechado, pois a narrativa precisa continuar no quadro seguinte. $\mathrm{O}$ efeito constituído aqui, usando recursos plásticos da temporalidade elabora $\mathrm{o}$ sentido da derrota uma vez que junta derrotas de tempos e espaços diferentes, mas com a mesma grandeza de fato.

As imagens de capa do jornal Diário de Pernambuco, assim como as manchetes dos jornais Agora São Paulo e Correio, atuam como um agente da memória da derrota da seleção brasileira na Copa do Mundo de 1950 para a seleção uruguaia. Afirma-se através de Wisnik (2008) que a lembrança e o acionamento do Maracanaço, vivenciado em meio a um cenário de dúvida entre o progresso/ ambição da sociedade brasileira e "a impotência infantilizada de um povo periférico e anarcóide", reafirma o caráter de síndrome do acontecimento ao cumprir a "função freudiana de rasurar o trauma através da sua infinita repetição fantasmática, diante de um conteúdo insuportável que se deu a ver". Síndrome explorada historicamente pela mídia esportiva e que influencia a cobertura de outro resultado colossal, a derrota de 7x1 em 2014. O Maracanaço reverbera através de uma relação interdiscursiva em que os enunciadores o utilizam para qualificar o 7x1 como "SALSICHAÇO" ou "VERGONHAÇO".

As capas que acionam o Maracanaço fazem questão de lembrar um acontecimento repleto de tragicidade incomparável com uma simples derrota. "A narrativa desenhada pela Copa expôs e maximizou, com a crueldade dos deuses, a própria oscilação vertiginosa entre a potência e a impotência, entre os voos do imaginário e a súbita reversão ao real" (WISNIK, 2008, p. 247- 
249). Simbolicamente, o 7x1 torna-se o acontecimento esportivo mais próximo do Maracanaço, inclusive o supera em termos de fracasso pelo o que se observa nas capas dos jornais. Ademais, causa uma quebra no epíteto "país do futebol" e faz pairar um sentimento de dúvida no futuro do futebol brasileiro, assim como fez o acontecimento de 1950 ao instaurar um descrédito na ideia de consolidação de um projeto coletivo nacional.

\section{Considerações finais}

Sempre que um analista abre seu fichário teóricometodológico para de lá tirar o prisma que o faz interpretar os fenômenos que procura entender, se depara com novas facetas deste. A análise de imagens não é uma tarefa fácil pois trata-se de um texto de uma gramática complexa e de organização anárquica. Isso devido à sua sintaxe e à ação mutante de alguns elementos, tais como a cor, que pode exercer funções da linha, do ponto, da textura, da dimensão, entre outros elementos plásticos. Pois bem, neste trabalho de análise sobre capas de jornal que retrataram a histórica derrota do Brasil para Alemanha, na Copa do Mundo de 2014, nos deparamos com a flexibilidade que o icônico tem para representar o real.

As fotografias usadas nas reportagens de capa driblaram, usando um trocadilho apropriado, os ângulos, enquadramentos e objetos do que é retratado no jornalismo esportivo do cotidiano. E o fizeram usando estrategicamente, mudando o modo de olhar os fatos e os efeitos que isso poderia gerar. Podemos identificar claramente o uso das fotos em que o todo é dado por uma parte, o que chamamos de "escorzo" pela teoria da imagem de Villafañe e Arnheim. Fenômeno causado pela angulação que não contempla a forma total dos objetos, chegando a interferir mesmo na sua estrutura, a ponto de causar estranhamento na identificação da imagem que é retratada. 
Vejamos, um jogo de elementos visuais postos de tal maneira na composição que são capazes de acentuar a tensividade da cena, sua assimetria e peso visual. Outro elemento tensivo usado foi a temporalidade, quando é ofertada ao leitor da foto, oportunidade de mais de um tempo de leitura na imagem. Recurso que imprime movimento à narrativas de imagens fixas, quebrando a monotonia e o desgaste de imagens já conhecidas.

Inevitável reconhecer a importância das imagens produzidas pelos meios de comunicação no esporte contemporâneo. Ela dá acesso aos acontecimentos a grande parte de seus fãs. Inevitável também reconhecer nas imagens a importância e o grau de comoção que pertence ao placar $7 \times 1$, que encontra apenas um referente em sua história, o Maracanaço. Afirma-se, portanto, o papel da imagem de agente construtor da história.

Notamos que a imagem, através de sua plasticidade, faz emergir sentidos acerca da derrota. É capaz de expressar e captar momentos e emoções únicas. Aproxima do leitor o choro, a desolação, o trágico e a tristeza, num efeito essencialmente pathêmico. Ademais, também é utilizada estrategicamente para ampliar os sentidos do texto verbal presente nas capas, revelando um jogo de relações interdiscursivas.

\section{Referências}

ARNHEIM, Rudolf. O poder do centro: um estudo das composições nas artes visuais. Lisboa: Edições 70, 1988.

BRAIT, Beth. Construção coletiva da perspectiva: história e alcance teórico-metodológico. In: FIGARO, Roseli (Org.). Comunicação e análise do discurso. São Paulo: Contexto, 2012. p. 79-98.

BRAINSTORM 9. Disponível em: < http://www.b9.com.br/50229/ brasil/50-capas-de-jornais-brasil-apos-derrota-de-7-x-1-para-a- 
alemanha/>. Acesso em: 9 jul. 2014

CAMPOS, Anderson Gurgel. A economia das imagens do esporte: produção, reprodução e valoração de bens imagéticos nos ambientes midiáticos dos megaeventos esportivos. 2014. Tese (Programa de Pós-Graduação em Comunicação e Semiótica) Pontifícia Universidade Católica de São Paulo, São Paulo.

CHARAUDEAU, Patrick. Discurso das mídias. São Paulo: Contexto, 2006.

COSTA, Leda Maria da. A trajetória da queda: as narrativas da derrota e os principais vilões da seleção brasileira em Copas do Mundo. 2008. Tese (Programa de Pós-Graduação em Letras) Universidade do Estado do Rio de Janeiro, Rio de Janeiro.

DAMÁSIO, Antônio Rosa. E o cérebro criou o homem. São Paulo: Companhia das Letras, 2011.

DELEUZE, Gilles. Lógica do sentido. São Paulo: Perspectiva, 1974.

FLUSSER, Vilém. Filosofia da caixa preta: ensaios para uma futura filosofia da fotografia. São Paulo: Hucitec, 2011.

KANDINSKY, Wassily. Ponto e linha sobre o plano. São Paulo: Martins Fontes, 1997.

MEYER, Philippe. O olho e o cérebro: biofilosofia da percepção visual. São Paulo: Editora UNESP, 2002.

POLVERINO, Leonardo. Manual del director de cine. Buenos Aires: Libertador, 2007. 
PORTARI, Rodrigo. O trágico, o futebol e o erotismo: a presença de uma tríade temática nas capas dos jornais populares do Brasil e Portugal. 2013. Tese (Programa de Pós-Graduação em Comunicação Social) - Universidade Federal de Minas Gerais, Belo Horizonte.

QUÉRÉ, Louis. Entre facto e sentido: a dualidade do acontecimento. Trajectos, Lisboa, v.6 n.6, p.59-76, 2005.

VERÓN, Eliseo. Fragmentos de um tecido. São Leopoldo: Unisinos, 2004.

VILLAFAÑE, Justo. Introducción a la teoria de la imagen. Madrid: Pirámide, 2000.

WISNIK, José Miguel. Veneno remédio: o futebol e o Brasil. São Paulo: Companhia das Letras, 2008. 